Article

\title{
Optimization of Antibacterial Properties of "Hybrid" Metal-Sputtered Superhydrophobic Surfaces
}

\author{
Dionysia Kefallinou ${ }^{1}$, Kosmas Ellinas ${ }^{1}{ }^{(0)}$, Thanassis Speliotis ${ }^{1}{ }^{(\mathbb{O},}$, Kostas Stamatakis $^{2}$, \\ Evangelos Gogolides ${ }^{1}$ (D) and Angeliki Tserepi ${ }^{1, *}$ \\ 1 Institute of Nanoscience and Nanotechnology, National Center for Scientific Research "Demokritos", \\ Patr. Gregoriou E' and 27 Neapoleos str., 15341 Aghia Paraskevi, Attiki, Greece; \\ d.kefallinou@inn.demokritos.gr (D.K.); k.ellinas@inn.demokritos.gr (K.E.); \\ t.speliotis@inn.demokritos.gr (T.S.); e.gogolides@inn.demokritos.gr (E.G.) \\ 2 Institute of Biosciences and Applications, National Center for Scientific Research "Demokritos", Patr. \\ Gregoriou E' and 27 Neapoleos str., 15341 Aghia Paraskevi, Attiki, Greece; kstam@bio.demokritos.gr \\ * Correspondence: a.tserepi@inn.demokritos.gr
}

Received: 14 November 2019; Accepted: 22 December 2019; Published: 30 December 2019

check for updates

\begin{abstract}
Bacterial attachment and colonization to hygiene sensitive surfaces, both public and nosocomial, as well as in food industry areas, poses a serious problem to human healthcare. Several infection incidents are reported, while bacterial resistance to antibiotics is increasing. Recently, novel techniques for the design of antibacterial surfaces to limit bacterial spreading have emerged, including bifunctional antibacterial surfaces with antifouling and bactericidal action. In this context, we have recently developed smart, universal, metal-sputtered superhydrophobic surfaces, demonstrating both bacterial repulsion and killing efficacy. Herein, we present the optimization process that led to the realization of these "hybrid" antibacterial surfaces. To this end, two bactericidal agents, silver and copper, were tested for their efficiency against Gram-negative bacteria, with copper showing a stronger bactericidal action. In addition, between two low surface energy coatings, the fluorinated-alkyl self-assembled chlorosilane layer from perfluorinated octyltrichlorosilane (pFOTS) solution and the fluorocarbon layer from octafluorocyclobutane $\left(\mathrm{C}_{4} \mathrm{~F}_{8}\right)$ plasma were both approved for their anti-adhesive properties after immersion in bacterial solution. However, the latter was found to be more efficient when engrafted with the bactericidal agent in shielding its killing performance. Furthermore, the thickness of the plasma-deposited fluorocarbon layer was optimized, in order to simultaneously retain both the superhydrophobicity of the surface and its long-term bactericidal activity.
\end{abstract}

Keywords: antibacterial activity; hybrid antibacterial surfaces; bifunctional surfaces; bactericidal agents; anti-adhesive surfaces; superhydrophobicity; plasma micro-nanotextured surfaces; Gram-negative bacteria

\section{Introduction}

Bacteria are renowned for their aptitude to colonize a diversity of materials, ranging from textiles, food packaging [1] public transportation, and aircraft interior surfaces, to medical implants, surgical equipment, and nosocomial surfaces. Bacterial infections are the second major cause of human mortality, being accountable for 17 million deaths annually [2], holding a global percentage of $64 \%$ hospital acquired infections [3,4]. Their spreading is fostered by the emergence of antibiotic resistance, with the development of multi-drug resistant strains of bacteria, as a result of the excessive use of antibiotics. We live in the era that bacteria not only develop resistance to antibiotics, but they also genetically acquire it from other strains, becoming so called "superbugs" [5]. Antimicrobial resistance 
now claims 25,000 deaths per year in the EU [6] and 23,000 in the USA [7], with a total of 700,000 losses globally, estimated to reach 10 million by 2050 [8]. While conventional antibiotics gradually lose their efficacy, there is a dire need for the emergence of alternative methods to tailor material surfaces, rendering them antibacterial so as to halt bacterial colonization and limit the spread of infections.

The main categorization of antibacterial surfaces involves: (i) bacteria repellent, antibiofouling surfaces, resistant to initial bacterial attachment and (ii) bactericidal surfaces, usually enriched with a bactericidal agent to kill bacteria.

For the fabrication of anti-adhesive surfaces, properties such as surface charge, free energy, zeta potential, and wettability $[9,10]$ are taken into account. Established surface modification strategies include chemical functionalization by grafting anti-adhesive polymers, such as polyethylene glycol (PEG), acting as a repellent coating [11,12], or physical alteration of the surface topography with the creation of surface roughness [13,14]. Many studies, however, focus on surface wettability, proving that both extreme wetting states, either superhydrophilicity or superhydrophobicity, hinder bacterial adhesion $[10,15]$.

Bactericidal surfaces are capable of killing or inactivating adhering bacteria [16]. Main fabrication techniques involve the incorporation of a biocide agent. Inorganic agents, recently reviewed by Bassegoda et al. [17], are usually preferred, due to their multiplicity of action, mainly attributed to the release of ions, which incommodes raising of bacterial resistance [18]. Among these agents, more widely investigated are silver $(\mathrm{Ag})[19,20]$, copper $(\mathrm{Cu})[21,22]$, and gold $(\mathrm{Au})$ [23], as well as some metal oxides, such as copper oxide $(\mathrm{CuO})[24,25]$, zinc oxide $(\mathrm{ZnO})$ [26], and titanium dioxide $\left(\mathrm{TiO}_{2}\right)[27,28]$. Cationic organic polymers are also employed, either synthetic, such as quaternary ammonium compounds (QACs) [29,30], or natural biocides, such as antimicrobial peptides (AMPs), chitosan, and lipids [31]. Finally, without grafting of a biocide, physical treatment for texturing high aspect ratio nanoprotrusions has been proven lethal for bacteria [32,33].

As can be deduced, a diversity of techniques is applied which, despite their general effectiveness, finally succumb to their innate limitations; anti-adhesive surfaces lose their efficacy with only a few bacteria adhered, since they will gradually form a biofilm, and bactericidal surfaces deprived of anti-adhesive properties are exposed to an aggregated bacterial population that hampers their bactericidal action. The combination of these two complementary approaches results in a "hybrid" antibacterial action with highly potent antibacterial surfaces of dual functionality.

Recent studies have focused on realizing such "smart" antibacterial surfaces. Among these, relaying on cases of proven anti-adhesive properties of superhydrophobic surfaces, including our previous work by Ellinas et al. [34], in which bacterial repulsion was studied on superhydrophobic surfaces fabricated by plasma micro-nanotexturing, a variety of these bifunctional surfaces use superhydrophobic surfaces for ensuring the antibacterial role. A selection of the abovementioned bactericidal agents is integrated in the design of superhydrophobic surfaces for the completion of their antibacterial duality. For example, Ren et al. [35] spray-coated glass substrates with superhydrophobic silica sol $\left(\mathrm{F}-\mathrm{SiO}_{2}\right)$ suspension, enriched with copper oxide $(\mathrm{CuO})$ nanoparticles as the bactericidal agent. Interestingly, Qian et al. [36] created hierarchical micro-nanostructures on stainless steel by sequential assembly of polydopamine (PDA) and silver (Ag) nanoparticles to a multilayer film, followed by $1 \mathrm{H}$, $1 \mathrm{H}, 2 \mathrm{H}, 2 \mathrm{H}$-perfluorodecanethiol (PFDT) hydrophobic fluorocarbon deposition to exhibit antibacterial activity against both Gram-negative (Escherichia coli) and Gram-positive (Staphylococcus aureus) bacteria. Dual-mode antibacterial activity was also demonstrated by Ozkan et al. [37], who reported a two-step aerosol-assisted chemical vapor deposition (AACVD) for growing copper nanoparticle-incorporated silicone (poly(dimethylsiloxane)-PDMS) film on glass substrates, whilst in Tripathy et al. [8] silanized copper hydroxide nanowires were transferred onto PDMS surface after curing and mechanical tearing. Heinonen et al. [38] prepared superhydrophobic surfaces on stainless steel, containing silver nanoparticles via the sol-gel method, and indicated the dependence of long-term silver bactericidal activity on the environmental $\mathrm{pH}$. Several examples of antibacterial surfaces based on wetting control or the combination of wetting control and a bactericidal agent can be found in a recent review paper [39]. 
In this context, in our previous work [34] we presented a simple method for the fabrication of universal, metal-sputtered superhydrophobic "hybrid" antibacterial surfaces exhibiting both anti-adhesive and bactericidal long-term activity against Gram-negative bacteria of concentrations as high as $2 \times 10^{9} \mathrm{cfu} / \mathrm{mL}$, one of the highest ever reported in the literature. One explanation for the beneficial anti-adhesive behavior of the proposed superhydrophobic surfaces is possibly their low friction properties [40]. Herein, we demonstrate the optimization process of the surface properties, meaning the appropriate combination of low surface energy coating and bactericidal agent that allows the expression of the dual antibacterial functionality of such surfaces. Two hydrophobic coatings were tested, a fluorocarbon layer deposited using octafluorocyclobutane $\left(\mathrm{C}_{4} \mathrm{~F}_{8}\right)$ plasma, and a fluorinated-alkyl self-assembled layer using perfluorinated octyltrichlorosilane (pFOTS) gas phase deposition. The two most broadly incorporated biocides, silver and copper, were also evaluated to identify which one performs more efficiently. More specifically, the choice of the bactericidal agent was made with respect to its long-term and broad-spectrum bactericidal performance, as a warranty for an antibacterial surface independent from the environmental conditions and the bacterial concentration. Further, the hydrophobic coating was chosen in terms of its ability to sustain the anti-adhesive properties of the surface, when combined with a metallic agent. The static contact angle of the chemically passivated, metal-sputtered micro-nanostructured surfaces was measured as a means of estimating the preservation of their superhydrophobic property. Finally, the thin distinctive boundary thickness of the chosen passivation coating is defined, so as to allow the interpretation of both the antifouling and bactericidal nature of the surface. The rationale was that the deposition time was adequate enough for the coating to sufficiently cover the nanostructured surface, shielding the superhydrophobicity of the surface and simultaneously ensuring controllable release of the metallic agent for long-term bactericidal action, all the while being short enough to avoid forming a very thick coating that would obstruct the metallic ions diffusion to the surface, impeding the surface bactericidal activity.

\section{Materials and Methods}

\subsection{Fabrication of Superhydrophobic Poly(Methyl Methacrylate) (PMMA) Surfaces}

\subsubsection{Micro-Nanotexturing of PMMA Surfaces}

Optically transparent poly(methyl methacrylate)/PMMA sheets of $2 \mathrm{~mm}$ thickness were purchased from IRPEN (Barcelona, Spain), cut down to $2 \mathrm{~cm} \times 2 \mathrm{~cm}$ plates, and cleaned using isopropyl alcohol (IPA) and deionized (DI) water. Plasma-induced micro-nanotexturing of the PMMA surfaces, i.e., plasma etching with parallel creation of roughness at the nano to micron scale $[41,42]$ was performed in a high-density radio frequency (RF) source helicon plasma reactor (Micromachining Etching Tool, MET, from Adixen-Alcatel, Anaheim, CA, USA). Oxygen $\left(\mathrm{O}_{2}\right)$ plasma was used for the texturing of the surfaces under the typical highly anisotropic conditions of $1900 \mathrm{~W}$ source power, $100 \mathrm{sccm} \mathrm{O}, 0.75 \mathrm{~Pa}$ gas pressure, $15^{\circ} \mathrm{C}, 250 \mathrm{~W}$ bias power, and duration of $10 \mathrm{~min}[43,44]$.

\subsubsection{Hydrophobic Film Deposition}

For rendering the micro-nanotextured PMMA surfaces superhydrophobic, the plasma-induced roughness needs to be combined with a low surface energy coating deposition [44,45]. In this work, two kinds of hydrophobic coatings were tested in terms of their competence to pinpoint both the anti-adhesive and bactericidal activity of the surfaces. Specifically, the first one is a fluorocarbon layer, plasma-deposited using octafluorocyclobutane $\left(\mathrm{C}_{4} \mathrm{~F}_{8}\right)$ gas under the following conditions: $900 \mathrm{~W}, 0 \mathrm{~V}$, $5.33 \mathrm{~Pa} \mathrm{C}_{4} \mathrm{~F}_{8}$, and a deposition rate of $68 \mathrm{~nm} \cdot \mathrm{min}^{-1}$ [43], and the second one, a (fluorinated-alkyl) self-assembled (chlorosilane) layer, gas phase-deposited from a $80 \mu \mathrm{L}$ solution pFOTS $(1 \mathrm{H}, 1 \mathrm{H}, 2 \mathrm{H}$, $2 \mathrm{H}$, perfluorooctyltrichlorosilane, $\left.\mathrm{CF}_{3}\left(\mathrm{CF}_{2}\right) 5 \mathrm{CH}_{2} \mathrm{CH}_{2}-\mathrm{SiCl}_{3}\right)$ in $2 \mathrm{~mL}$ hexane $(3 \% v / v)$ under controlled flow of $50 \mu \mathrm{L} \cdot \mathrm{min}^{-1}$ inside a vacuum desiccator for an approximate time of $2 \mathrm{~h}$ at room temperature, 
followed by heating at $95{ }^{\circ} \mathrm{C}$ for $10 \mathrm{~min}$ for solvent removal. Of note, prior to pFOTS deposition, oxygen activation was performed by plasma treatment in the same helicon plasma reactor in typical conditions of $1900 \mathrm{~W}, 100 \mathrm{sccm} \mathrm{O}, 1.33 \mathrm{~Pa}, 15^{\circ} \mathrm{C}, 0$ bias power, and $20 \mathrm{~s}$ [41].

\subsection{Metal Deposition}

Copper $(\mathrm{Cu})$ and silver $(\mathrm{Ag})$ thin film deposition was performed via sputtering on both untreated and micro-nanotextured PMMA surfaces using an RF magnetron sputtering reactor CVE 401 (Cooke Vacuum Products Inc., Redding, CT, USA) with argon (Ar) as inert gas under operating parameters of base pressure $5 \times 10^{-8}$ Torr, power density $1.41 \mathrm{~W} / \mathrm{cm}^{2}$, Ar pressure $3 \mathrm{mTorr}$.

Metal deposition was performed on PMMA surfaces prior to any hydrophobic layer deposition. Metal thickness was measured on untreated control Si substrates, processed simultaneously with the PMMA surfaces. Specifically, a surface profilometer (XP-2 Stylus Profilometer, Ambios Technology, Inc., Santa Cruz, CA, USA) was used to measure the step between the metal-sputtered and the clean area of the control Si substrates. Taking into account the deposition time, the deposition rate $\left(\mathrm{nm} \cdot \mathrm{s}^{-1}\right)$ was defined. The desired thickness of the sputtered metal film on the PMMA surfaces was achieved by implementing the appropriate deposition time, at the same sputtering parameters used for the calibrated Si substrates. Thus, the 2,5, and $10 \mathrm{~nm}$ metal film thicknesses were determined according to the deposition time used for these film thicknesses. It should be noted that on the rough PMMA surfaces, the sputtered metal is not expected to form a film of uniform thickness.

\subsection{Surface Characterization}

Scanning electron microscopy (SEM) was performed in a JSM-7401F instrument from JEOL (Tokyo, Japan) for the characterization of surface morphology of PMMA plates after plasma treatment. The wettability study of the micro-nanotextured surfaces was performed by static and dynamic water (surface tension $72 \mathrm{mN} \cdot \mathrm{m}^{-1}$ ) contact angle measurements, using a Digidrop System (GBX, Romans-sur-Isère, France). Water static contact angle (WSCA) was measured by depositing a typical volume of $5 \mu \mathrm{L}$, whilst contact angle hysteresis (CAH) was evaluated by measuring the advancing and receding contact angle during continuous increase and decrease of the droplet volume, respectively. Contact angle hysteresis refers to the difference between advancing and receding contact angle. Extrapolation of the three phase boundaries, i.e., solid/liquid, solid/vapor, and liquid/vapor to the common intersection line gives the contact angle of the solid/liquid interface, as a result of a fitting procedure from a series of captured photographs (image resolution $768 \times 572$ pixels) [41] . All measurements were carried out at ambient conditions with a minimum of three measurements taken in different spots of each sample, the average value of which was taken into account with an uncertainty of $\pm 2^{\circ}$ [41]. The thickness of the low surface energy coatings was measured using ellipsometry (Spectroscopic Ellipsometer, J.A. Woollam Co., Lincoln, NE, USA) on untreated control Si wafers, processed simultaneously with the PMMA surfaces.

\subsection{Bacterial Culture}

Unicellular Gram-negative cyanobacteria Synechococcus sp. PCC7942 were purchased from the Collection Nationale de Cultures de Microorganismes (CNCM), Institut Pasteur (Paris, France). They were cultured in BG11 basal medium ( $\mathrm{pH}$ 7.5) [46] and incubated under white fluorescent light $\left(100 \mu \mathrm{E} \cdot \mathrm{m}^{-2} \cdot \mathrm{s}^{-1}\right)$ in an orbital shaker incubator (Gallenkamp INR-400, Gallenkamp, UK) at $31{ }^{\circ} \mathrm{C}$, supplied with $5 \% v / v \mathrm{CO}_{2}$ in air. Cells were harvested during their exponential growth period, and the tracking of their growth was performed by measuring their chlorophyll $(\mathrm{Chl} \alpha)$ concentration in a UVIDEC-610 spectrophotometer (Jasco, Tokyo, Japan). Chlorophyll $\alpha$ concentration was determined in N,N-dimethylformamide (DMF) extracts of cell pellets [47]. 


\subsection{Bacterial Adhesion Study}

For the study of cyanobacterial adhesion on untreated and superhydrophobic PMMA surfaces, two kinds of micro-nanotextured superhydrophobic PMMA surfaces were created, both oxygen plasma-treated, and differentiated in terms of the deposited low surface energy coating, which is either the fluorocarbon layer from octafluorocyclobutane $\left(\mathrm{C}_{4} \mathrm{~F}_{8}\right)$ plasma or the chlorosilane layer from perfluorooctyltrichlorosilane ( $\mathrm{pFOTS}$ ) solution. Prior to plasma micro-nanotexturing, parallelogram wells of dimensions $50 \mathrm{~mm}$ (length) $\times 20 \mathrm{~mm}$ (width) $\times 1 \mathrm{~mm}$ (depth) were hot embossed on the PMMA substrates. The bottom of the wells was either left untreated or was plasma micro-nanotextured and hydrophobized, as aforementioned, and filled with $1 \mathrm{~mL}$ of bacterial solution of $2.3 \times 10^{9} \mathrm{cfu} / \mathrm{mL}$. The wells were kept inside an incubator (LabTech, Daihan LabTech Co., LTD, Namyangju, Korea) that provided the appropriate conditions for bacterial growth, namely $28^{\circ} \mathrm{C}$, light, and a relatively high humidity $(>50 \%)$. Bacterial adhesion was studied every $24 \mathrm{~h}$ for a total time period of $72 \mathrm{~h}$, using fluorescence microscopy (Axioskop 2 plus, Carl Zeiss, Oberkochen, Germany). In particular, at the end of every $24 \mathrm{~h}$, fluorescence intensity images were captured using ImagePro software (version 6.0), from which bacterial adhesion was quantified by calculating the \% bacterial coverage. Each \% bacterial coverage value has been averaged over 90 measurements (30 images $\times 3$ repetitions), accompanied by the respective mean deviation.

\subsection{Antibacterial Susceptibility Testing Method}

An in situ quantitative method for the assessment of the antibacterial properties of the fabricated surfaces was used, based on in vivo measurements of chlorophyll (Chl $\alpha)$ fluorescence of cyanobacteria directly deposited on the surfaces, as a faithful representation of their real life conditions [48,49]. The method has been tested and evaluated for its accuracy compared to the AATCC 100-2004 method, which is used as a standard for the evaluation of the antibacterial properties [48]. More specifically, it has been demonstrated [49] that this method employing cyanobacteria can monitor the behavior of either phototrophic or heterotrophic bacterial metabolic pathways on antibacterial surfaces. Therefore, the cyanobacteria Synechococcus sp. PCC 7942 have been used not as only one species of bacteria, but as typical Gram-negative bacteria.

In brief, droplets of $50 \mu \mathrm{L}$ Synechococcus sp. PCC7942 on each surface were kept, prior to measurement, in complete darkness for $10 \mathrm{~min}$ to ensure the establishment of the dark-adapted cells. Chl $\alpha$ fluorescence intensity $F_{0}$ was measured upon excitation using a PEA-fluorometer (PEA, Hansatech Instruments Ltd., Norfolk, UK), every $24 \mathrm{~h}$ for a time period of 20-27 days, and each $F_{0}$ value was averaged upon 36 measurements ( 3 measurements on each surface $\times 3$ surfaces $\times 4$ repetitions). As a means of determining the evolution of the bacterial population, the \% change $\left(M_{i}\right)$ in $\mathrm{Chl} \alpha$ fluorescence after $i$ days was calculated, according to the equation:

$$
M_{i}=\frac{F_{0_{i}}-F_{0_{0}}}{F_{0_{0}}} \times 100 \%
$$

where $F_{0_{0}}$ is the fluorescence value at zero contact time and $F_{0_{i}}$ is the fluorescence value after $1,2, \ldots, i$ days. Of notice, $F_{0}$ has been proved to be directly correlated to the bacterial population and the $M_{i}$ evolution to the increase/decrease of the population [48]. In particular, negative values of the $M_{i}$ index are indicative of a decline in bacterial population, therefore of an antibacterial behavior of the testing surface. An exception to this is the lag phase of the first days of cyanobacteria in contact with the surface, where the $M_{i}$ negative values are attributed to the bacterial adjustment to the new conditions. The obtained $M_{i}$ results are presented as the averaged values of each surface on the specified day, accompanied by their standard deviation. 


\section{Results and Discussion}

\subsection{Micro-Nanotextured Superhydrophobic Surfaces}

Highly anisotropic oxygen $\left(\mathrm{O}_{2}\right)$ plasma treatment was applied at the abovementioned conditions (see Section 2.1.1) for the texturing of the PMMA surfaces. As previously shown [44], these $\mathrm{O}_{2}$ plasma conditions lead to very high surface roughness on PMMA surfaces, most appropriate for ensuring superhydrophobicity after the additional fluorocarbon layer deposition. Indeed, 10 min etching of the surfaces resulted in a dual-roughness topography, with randomly distributed coarse scale microfilaments bearing fine scale nanofeatures on their top. SEM images (Figure 1) are indicative of the micro-nanotextured topography induced by the oxygen plasma processing

In addition to the induced surface topography, this plasma treatment of the PMMA surfaces also invokes chemical modification [50]. In fact, following X-ray photoelectron spectroscopy (XPS, Kratos Axis Ultra DLD, Kratos Analytical Ltd., Manchester, UK) analysis of untreated and treated PMMA surfaces, additional components were shown to be introduced on the surface after plasma treatment, such as carbonyl $(\mathrm{C}=\mathrm{O})$, carbonate $\left(\mathrm{O}_{2}-\mathrm{C}=\mathrm{O}\right)$, and $\mathrm{O}-\mathrm{C}-\mathrm{O}$ chemical groups, leading to significant increase of [O] from $23 \%$ to $38 \%$, and reduction of the [C] content from $77 \%$ to $40 \%$, on the surface of treated PMMA. Moreover, an increase of the Al content of the surface from 0\% to 5\% (after 15 min treatment) has been demonstrated, as a result of sputtering of the plasma etcher dome.

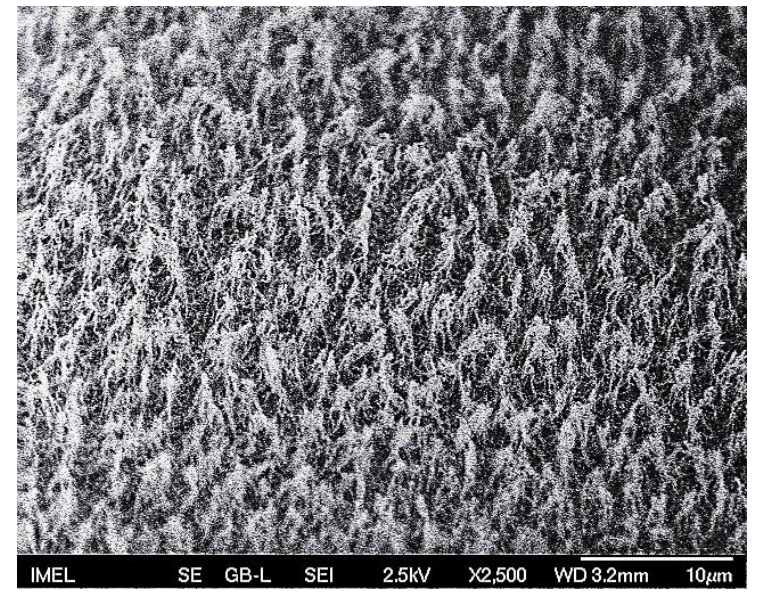

(a)

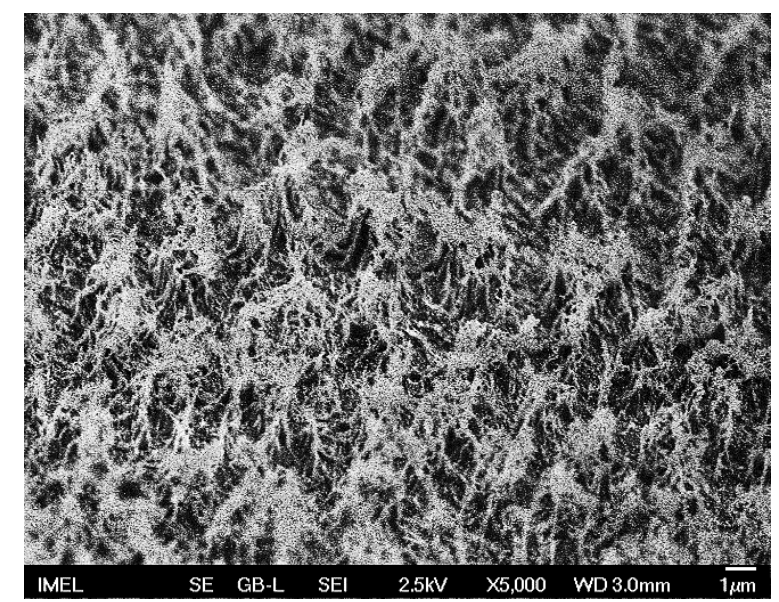

(b)

Figure 1. Scanning electron microscopy (SEM) images of micro-nanotextured poly(methyl methacrylate)/PMMA surfaces after 10 min highly anisotropic oxygen $\left(\mathrm{O}_{2}\right)$ plasma treatment at $(\mathbf{a}) \times 2500$ magnification and (b) $\times 5000$ magnification for better visualization of the induced nanotopography. The induced micro-nanoroughness is accompanied by chemical modification of the PMMA surfaces, with the introduction of carbonyl $(\mathrm{C}=\mathrm{O})$, carbonate $\left(\mathrm{O}_{2}-\mathrm{C}=\mathrm{O}\right)$ and $\mathrm{O}-\mathrm{C}-\mathrm{O}$ chemical groups.

After surface micro-nanotexturing, PMMA surfaces were deposited with two kinds of low surface energy coatings, either the fluorocarbon layer from octafluorocyclobutane $\left(\mathrm{C}_{4} \mathrm{~F}_{8}\right)$ plasma, or the fluorinated chlorosilane layer from perfluorooctyltrichlorosilane ( $p F O T S$ ) solution, to be rendered superhydrophobic. For verifying the wetting properties of the textured surfaces, water static contact angle (WSCA) measurements were performed, alongside with dynamic measurements of the advancing and receding contact angles, resulting in the respective contact angle hysteresis (CAH) for both the $10 \mathrm{~s}$ fluorocarbon and the 2-h chlorosilane layer deposition processes (Table 1). As presented in Table 1, both surfaces exhibit high water static contact angles $\left(>155^{\circ}\right)$ and low hysteresis $\left(<5^{\circ}\right)$, verifying their superhydrophobic character. More specifically, Figure 2 shows a water droplet on the 10 min $\mathrm{O}_{2}$ plasma-etched PMMA surfaces, deposited with the hydrophobic layer from either $\mathrm{C}_{4} \mathrm{~F}_{8}$ plasma or pFOTS solution. 


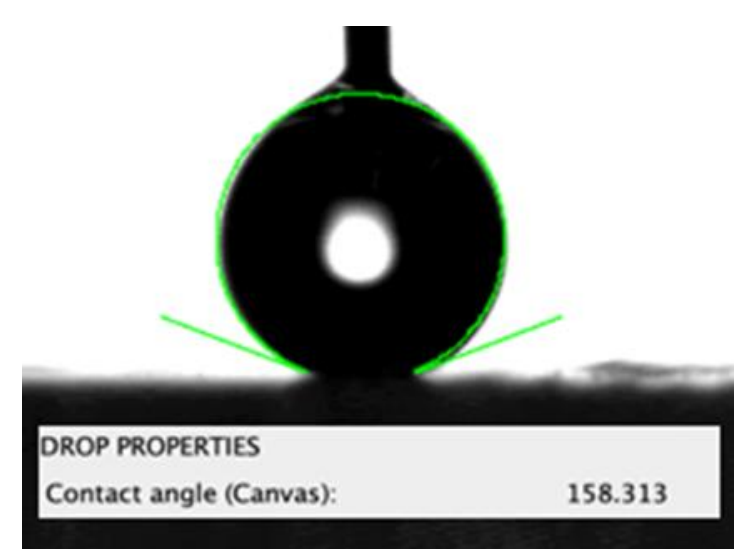

(a)

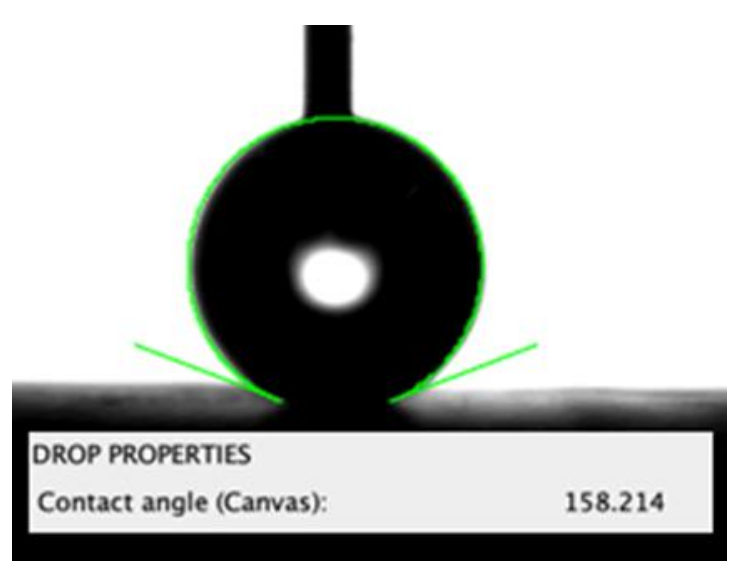

(b)

Figure 2. Photographs of a $5 \mu \mathrm{L}$ water droplet on an oxygen plasma micro-nanotextured (10 $\mathrm{min}$ ) superhydrophobic PMMA surface coated with (a) a fluorocarbon layer from $\mathrm{C}_{4} \mathrm{~F}_{8}$ plasma deposition $(10 \mathrm{~s})$ and (b) a fluorinated chlorosilane layer from pFOTS solution.

Table 1. Water static contact angle measurements of oxygen plasma micro-nanotextured superhydrophobic PMMA surfaces after the deposition of either a fluorinated chlorosilane layer from perfluorinated octyltrichlorosilane (pFOTS) solution or a fluorocarbon layer from $\mathrm{C}_{4} \mathrm{~F}_{8}$ gas discharge, alongside with the respective advancing, receding contact angles and contact angle hysteresis.

\begin{tabular}{ccccc}
\hline Precursors & $\begin{array}{c}\text { Water Static Contact } \\
\text { Angle (WSCA) }\left({ }^{\circ}\right)\end{array}$ & $\begin{array}{c}\text { Advancing Contact } \\
\text { Angle (ACA) }\left({ }^{\circ}\right)\end{array}$ & $\begin{array}{c}\text { Receding Contact } \\
\text { Angle (RCA) }\left({ }^{\circ}\right)\end{array}$ & $\begin{array}{c}\text { Contact Angle } \\
\text { Hysteresis (CAH) }\left({ }^{\circ}\right)\end{array}$ \\
\hline pFOTS & 158 & 158 & 156 & 2 \\
$\mathrm{C}_{4} \mathrm{~F}_{8}$ & 158 & 158 & 157 & 1 \\
\hline
\end{tabular}

The wetting properties of a surface determine the contact area between a liquid and the surface. The liquid-solid contact area is different for an untreated and a micro-nanotextured superhydrophobic surface, meaning that for the same volume bacterial concentration, a different bacterial surface density corresponds to each surface, resulting in a different bacterial number eventually interacting with the surface. As a means of quantifying this difference in liquid-solid contact area, a droplet of 50 $\mu \mathrm{L}$ bacterial solution was dispensed on each surface and the contact area diameter of each droplet was measured using the GBX Digidrop System. For the untreated surfaces, the contact line diameter was measured $d_{U}=12.9 \pm 0.3 \mathrm{~mm}$, producing a contact surface area $S_{U}=130 \mathrm{~mm}^{2}$, while for the superhydrophobic surface, the contact line diameter was $d_{\mathrm{SH}}=2.8 \pm 0.1 \mathrm{~mm}$ and the surface area $S_{\mathrm{SH}}=6.1 \mathrm{~mm}^{2}$. Indeed, the two contact surface areas differ by a factor $b=\frac{S_{\mathrm{U}}}{S_{\mathrm{SH}}}=21$, indicative of the normalization demanded if untreated and superhydrophobic surfaces are compared directly (not such comparison performed in this work).

\subsection{Bacteria Anti-Adhesive Surfaces}

The anti-adhesive properties of the as here produced superhydrophobic surfaces were tested after immersion in bacterial solution. In this study, parallelogram wells of untreated and superhydrophobic surfaces of the two types of hydrophobic coatings were filled with $1 \mathrm{~mL}$ bacterial solution of $2.3 \times 10^{9} \mathrm{cfu} / \mathrm{mL}$ concentration and studied using fluorescence microscopy for 3 days. Representative fluorescence microscope images of the bacterial propagation on the three different substrates are provided in Table 2 . The resulting bar diagram of the \% bacterial coverage at the end of every $24 \mathrm{~h}$ and throughout the experiment is shown in Figure 3. 
Table 2. Fluorescence microscope images of bacterial propagation on three different surfaces, i.e., untreated PMMA, and superhydrophobic deposited with either chlorosilane layer from pFOTS solution, or fluorocarbon layer from $\mathrm{C}_{4} \mathrm{~F}_{8}$ plasma micro-nanotextured PMMA surfaces, during the 72-h bacterial adhesion study $\left(2.3 \times 10^{9} \mathrm{cfu} / \mathrm{mL}\right)$.
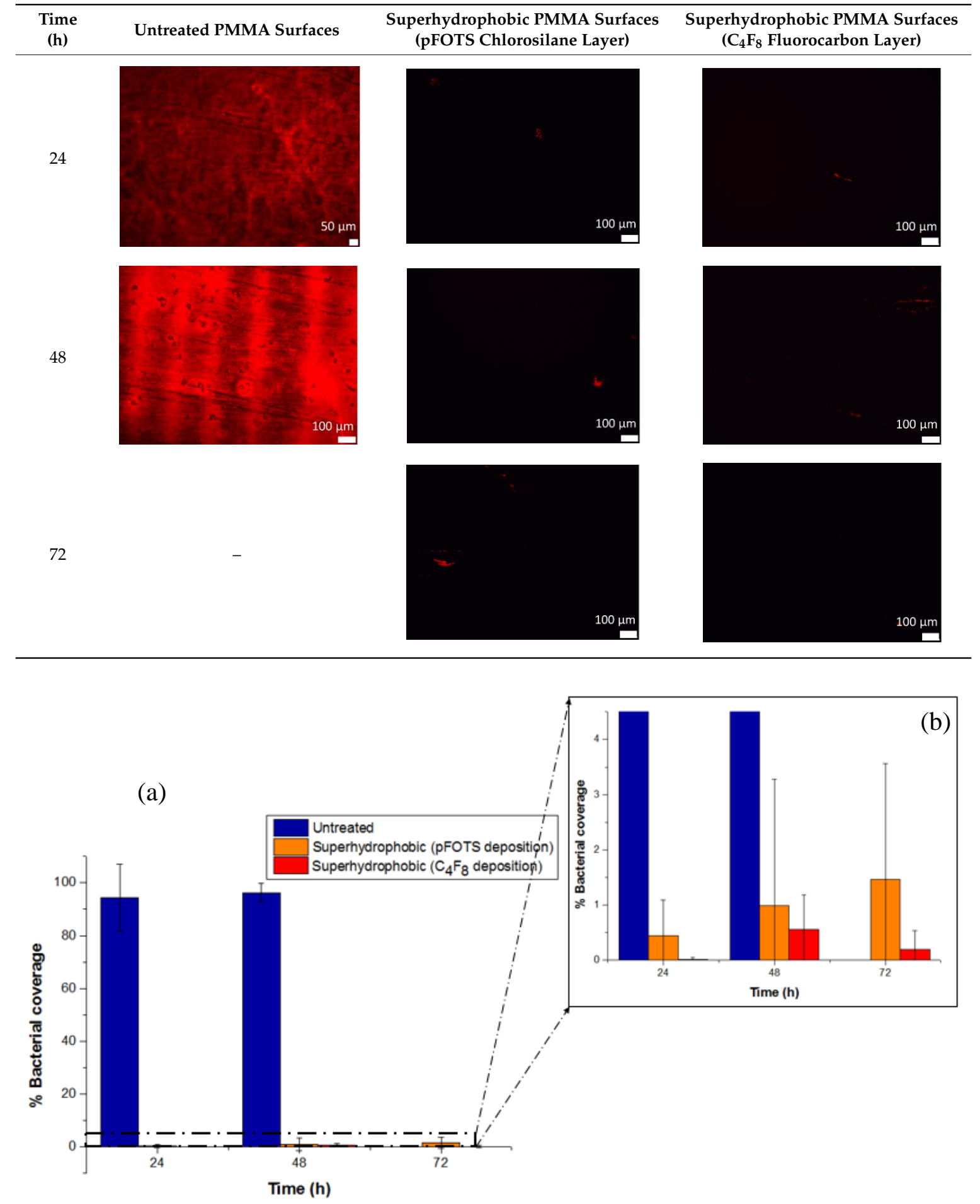

Figure 3. (a) Percentage bacterial coverage of untreated and superhydrophobic PMMA surfaces (deposition of chlorosilane layer from pFOTS solution, or fluorocarbon layer from $\mathrm{C}_{4} \mathrm{~F}_{8}$ plasma). (b) Magnified image to clearly present the low \% bacterial coverage (not exceeding 1.5\%) of both superhydrophobic surfaces, demonstrating superior bacteria anti-adhesive surfaces. 
As it can be deducted from both Table 2 and Figure 3, bacteria propagate on the untreated PMMA surfaces, yielding $94 \%$ bacterial coverage after $24 \mathrm{~h}$, further increased to higher than $96 \%$ at $48 \mathrm{~h}$. On the contrary, both the chlorosilane and the fluorocarbon coated superhydrophobic surfaces exhibit significantly low $\%$ bacterial coverage, not surpassing $1.5 \%$. Conclusively, this study has revealed a straightforward anti-adhesive, antibacterial performance for both kinds of hydrophobic layer deposited, i.e., the chlorosilane layer from pFOTS $(1 \mathrm{H}, 1 \mathrm{H}, 2 \mathrm{H}, 2 \mathrm{H}$, perfluorooctyltrichlorosilane) solution, and the fluorocarbon layer from octafluorocyclobutane $\left(\mathrm{C}_{4} \mathrm{~F}_{8}\right)$ plasma, superhydrophobic surfaces.

The anti-adhesive properties of these superhydrophobic surfaces can perfectly contribute to their antibacterial behavior by delaying the bacterial biofilm formation. However, considering the bacterial potential to exponentially proliferate, even a limited bacterial number attached on superhydrophobic surfaces can progressively evolve to an extended bacterial population after several hours of immersion in bacterial solution (exceeding the as here studied $72 \mathrm{~h}$ ), thereby shielding the superhydrophobic surfaces with only short-term antibacterial protection [34]. Therefore, in order to achieve long-term antibacterial activity, the engraftment of a bactericidal agent on superhydrophobic surfaces is attempted, which will secure the extermination of any remaining bacteria, fulfilling the bifunctional antibacterial role of the finally produced "hybrid" metal-sputtered superhydrophobic surfaces.

\subsection{Bactericidal Activity of Copper and Silver}

As reported in our previous work [34], the incorporation of a bactericidal agent is essential for ensuring long-term antibacterial action, in terms of constructing the ultimate, hybrid antibacterial surface. In this context, in order to determine the best antibacterial agent, copper and silver, two of the most frequently used bactericidal agents, were sputtered on untreated PMMA surfaces forming a $10 \mathrm{~nm}$ film. Three different bacterial concentrations of $2.3 \times 10^{9}, 4.6 \times 10^{9}$, and $9.3 \times 10^{9} \mathrm{cfu} / \mathrm{mL}$ were tested in order to demonstrate the range of antibacterial action for the two metal agents. In all cases, $50 \mu \mathrm{L}$ of the corresponding concentration of Synechococcus sp. PCC 7942 were deposited on each surface and their antibacterial behavior was measured according to the Chl $\alpha$ fluorescence emission, as captured by the in situ antimicrobial susceptibility testing method [48] throughout the exponential bacterial growth period. The resulting $M_{i}$ index evolution of the two different metallic sputtered surfaces is presented separately for each bacterial concentration, with respect to an untreated pristine PMMA surface in Figure 4.

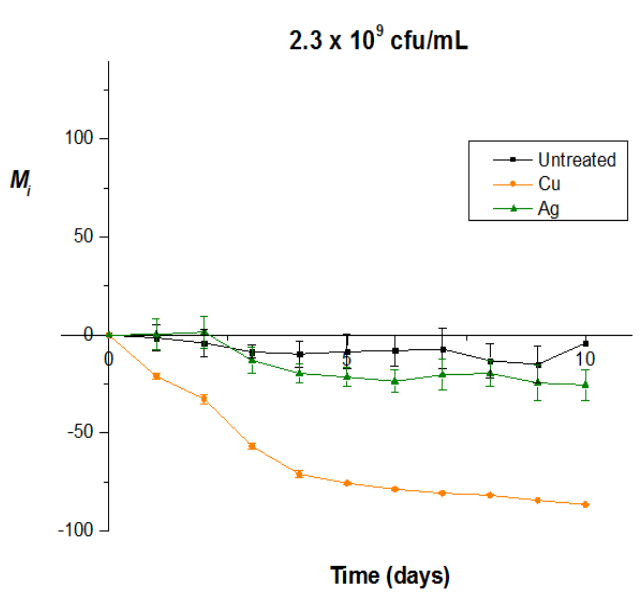

(a)

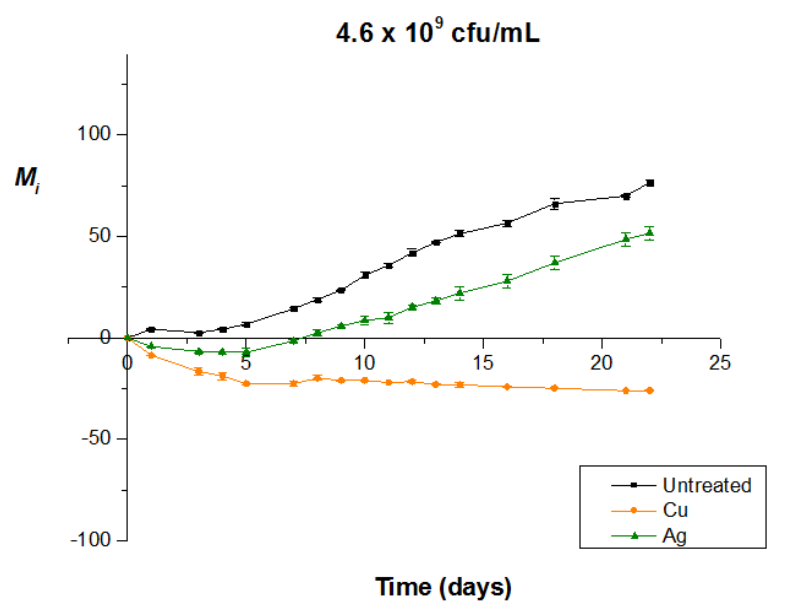

(b)

Figure 4. Cont. 


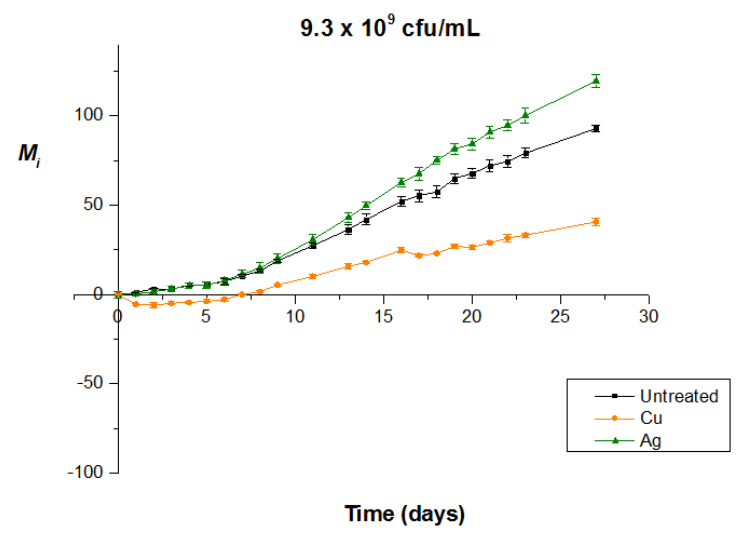

(c)

Figure 4. Bactericidal activity of copper and silver enriched untreated PMMA surfaces (i.e., without plasma micro-nanotexturing) for various Synechococcus sp. PCC 7942 concentrations of (a) $2.3 \times 10^{9} \mathrm{cfu} / \mathrm{mL}$, (b) $4.6 \times 10^{9} \mathrm{cfu} / \mathrm{mL}$, and (c) $9.3 \times 10^{9} \mathrm{cfu} / \mathrm{mL}$. In all concentrations, copper outperforms silver, all the while enabling long-term maintenance of bacteria-killing properties.

Figure 4 clearly reveals copper's superiority as a bactericidal agent for the entire concentration range. More specifically, at the low concentration of $2.3 \times 10^{9} \mathrm{cfu} / \mathrm{mL}$, though silver presents a clear bactericidal behavior, as depicted from the negative $M_{i}$ values, the decline in bacterial population caused by copper at the end of the experiment (day 10) is as much as 3.4 times greater. Added to this, the limited duration of the experiment (10 days) does not ensure the preservation of silver's killing potential with the evolving biofilm formation, given its limited contact killing properties in the specific conditions. Moving on to the concentration of $4.6 \times 10^{9} \mathrm{cfu} / \mathrm{mL}$, silver remains biocidal only until the 7 th day of experiment in a total of 22 days, as proven by the negativity of its $M_{i}$ index, which is not the case for copper, which appears to sustain its bactericidal activity until the 22nd and last experiment day, keeping an approximately steady performance. As for the highest concentration of $9.3 \times 10^{9} \mathrm{cfu} / \mathrm{mL}$, silver-sputtered surfaces present an absence of bactericidal activity, allowing normal, exponential development of bacterial population, similar to the one on the untreated surface, until biofilm formation (due to experimental errors, it is difficult to argue whether the Ag-coated surface is indeed worse than the untreated one). On the contrary, although copper-sputtered surfaces seize to cause decrease of the bacterial population on day 8 , they still manage to retard the bacterial exponential growth even after biofilm formation, preserving steadily lower values of $M_{i}$ index compared to the ones of the reference or silver surface until the end of the experiment (day 27). We can therefore safely conclude that at concentrations equal to or higher than $4.6 \times 10^{9} \mathrm{cfu} / \mathrm{mL}$, silver is no longer capable of acting as bactericidal agent or it has already been consumed, whereas copper retains its bactericidal activity, gaining an advantage in terms of both breadth of bacterial concentration and long-term bactericidal action.

These results comply with the physico-chemical properties of each metallic agent. More specifically, silver's bactericidal activity is promoted when found in oxidative condition AgO [51,52], which allows dissolution to $\mathrm{Ag}^{+}$ions that primarily invoke bacterial damage [52,53]. However, oxidation of metallic silver and dissolution to the ionic condition $\mathrm{Ag}^{+}$is $\mathrm{pH}$-dependent, decreasing with increasing $\mathrm{pH}$ and being favored in acidic environments $[51,54]$. This is not the case of our experimental conditions, with the cyanobacteria even creating a mildly alkaline field. While the antibacterial role of metallic silver cannot be excluded, hindered release of $\mathrm{Ag}^{+}$ions ally with the decreased killing efficiency of silver compared to copper.

On the other hand, copper remains active in ambient conditions, where despite its metallic form, it can be found oxidized as $\mathrm{Cu}_{2} \mathrm{O}$, which is its main oxidizing state, and $\mathrm{CuO}$, or in the ionic condition $\mathrm{Cu}^{2+}[51]$. In any case, the release of $\mathrm{Cu}^{2+}$ ions, which is the main contributor in the killing 
process [55,56], initiates upon contact with the bacteria [57]. Copper has been proven advantageous in contact killing compared to other metals, including silver [51], and lethal in dry conditions $[56,58]$ that better approach our experimental conditions, with a reportedly even higher killing rate in dry copper surfaces compared to moist ones [58]. Its superiority in dry contact can be interpreted by its three-stage attack to bacteria [56], which involves primarily cell membrane rupture and loss of cytoplasmic content due to both released copper ions and applied stress, followed by generation of toxic reactive oxygen species (ROS) by a Fenton-type reaction [59] that damage cell functionality by inhibiting respiration and inactivating proteins, and finally, leading to DNA degradation. Added to the above, copper exhibits enhanced bactericidal performance towards specifically autotrophic photosynthetic organisms, due to the $\mathrm{Cu}^{2+}$ copper ion's ability to obstruct the photosynthetic procedure by obstructing the electron transport in Photosystem II [48]. However, in our study, its bactericidal activity cannot be exhausted to its capacity to impede photosynthesis, as reaffirmed by the universality of the as here used chlorophyll $\alpha$ fluorescence based antimicrobial susceptibility testing (AST) method, which is affected by antibacterial agents via mechanisms offending all Gram-negative bacteria, regardless of their autotrophic or heterotrophic metabolic pathways [49]. Thus, with cyanobacterium Synechococcus sp. PCC 7942 used as a typical Gram-negative bacterium, such as E-coli that is used routinely in all standard antibacterial methods [60], it can be safely concluded that copper's bactericidal performance applies to all Gram-negative bacteria. Supporting this is the evident outperformance of copper and its broad range of activity even in concentrations as high as $9.3 \times 10^{9} \mathrm{cfu} / \mathrm{mL}$, while overall its antibacterial activity has been extensively verified towards both Gram-positive [61] and Gram-negative bacteria [62].

\subsection{Evaluation of Copper Film Thickness and Hydrophobic Coating Type Targeting a Bifunctional Antibacterial Activity}

Copper, therefore, rose as the most suitable agent for long-term antibacterial action. Keeping in mind the need for dual antibacterial activity, a hydrophobic coating should be chosen so as to allow the bactericidal action of the agent, and at the same time preserve the anti-wetting properties of the surface that ensure its anti-adhesive behavior. For this reason, we tested two kinds of hydrophobic coatings, a fluorocarbon layer from octafluorocyclobutane $\left(\mathrm{C}_{4} \mathrm{~F}_{8}\right)$ gas discharge, and a self-assembled fluorinated chlorosilane (pFOTS- $1 \mathrm{H}, 1 \mathrm{H}, 2 \mathrm{H}, 2 \mathrm{H}$, perfluorooctyltrichlorosilane) layer. Specifically, after oxygen plasma micro-nanotexturing, PMMA surfaces were copper-sputtered in three different film thicknesses of 2, 5, and $10 \mathrm{~nm}$ (as measured on flat $\mathrm{Si}$ surfaces), and for each of them, both low surface energy coatings were tested, the fluorocarbon $\mathrm{C}_{4} \mathrm{~F}_{8}$ plasma-deposited for $30 \mathrm{~s}$, resulting in $33.9 \pm 0.9 \mathrm{~nm}$ thickness and the chlorosilane layer for $2 \mathrm{~h}$.

The maintenance of the wetting properties of the surfaces with the implantation of the bactericidal agent was quantitatively specified by measuring the static water contact angle of the passivated surfaces for each different copper film thickness. The results of our measurements are summarized in Table 3.

Table 3. Water static contact angle measurements of plasma micro-nanotextured superhydrophobic PMMA surfaces after the deposition of a fluorinated chlorosilane layer from pFOTS or a fluorocarbon layer from $\mathrm{C}_{4} \mathrm{~F}_{8}$ gas discharge, for various underlying copper film thickness.

\begin{tabular}{ccc}
\hline \multirow{2}{*}{ Copper Thickness $(\mathrm{nm})$} & \multicolumn{2}{c}{ Water Static Contact Angle (WSCA) $\left(^{\circ}\right)$} \\
\cline { 2 - 3 } & pFOTS & $\mathrm{C}_{\mathbf{4}} \mathrm{F}_{\mathbf{8}}$ \\
\hline 2 & 100 & 157 \\
5 & 50 & 157 \\
10 & $<50$ & 159 \\
\hline
\end{tabular}

As seen in Table 3, at high copper thickness the fluorinated chlorosilane layer did not successfully bind onto the substrate, presenting low WSCA. The highest value was measured on the $2 \mathrm{~nm}$ copper film thickness. On the contrary, the fluorocarbon layer which is physically deposited on the surface 
exhibited high water static contact angle and low hysteresis (contact angle hysteresis lower than $5^{\circ}$ ) and the surface became superhydrophobic in all cases. This behavior can be explained by the different properties of the hydrophobic films. The chlorosilane layer from pFOTS solution requires hydroxyl formation in order to enable chemical binding with $\mathrm{Cl}$. The deposition of the bactericidal agent (copper) impedes the creation of a uniform layer from pFOTS and by increasing the copper coverage of the surface, hydroxyl formation is hindered, resulting in failure of pFOTS coating. That is not the case for the fluorocarbon $\mathrm{C}_{4} \mathrm{~F}_{8}$-deposited layer, which can be more easily stabilized on the surface with no need for oxygen pretreatment, thereby deposited more uniformly and, thus, presenting wetting properties independent from the copper film enrichment.

We should note here that without the engraftment of a bactericidal agent, the as here produced oxygen plasma-etched micro-nanotextured surfaces, deposited with the chlorosilane layer from pFOTS, were successfully proved superhydrophobic (Section 3.1) and have also been previously extensively produced $[63,64]$. Likewise, their superhydrophobic and anti-adhesive properties were further sustained after the immersion in bacterial solution for 3 days (Section 3.2).

Given that less than $2 \mathrm{~nm}$ of copper thickness is not easily controllable and may not be sufficient as bactericidal agent, we opt for the fluorocarbon layer as the hydrophobic coating on the copper-sputtered plasma-etched PMMA surfaces. In this way, greater copper concentration (resulting from at least $10 \mathrm{~nm}$ thickness) can be sputtered, to prolong the copper ions $\mathrm{Cu}^{2+}$ diffusion and release, and consequently, the bactericidal activity of the "hybrid" antibacterial surface.

\subsection{Optimization of the Plasma-Deposited Hydrophobic Coating Thickness}

Having reassured the anti-adhesive behavior and the preservation of the superhydrophobic character of the surfaces with the fluorocarbon coating for an adequate copper film thickness of $10 \mathrm{~nm}$, the bactericidal activity of the surfaces needs to be examined for various thicknesses of the hydrophobic coating for unhindered copper ion diffusion through it to enable direct and efficient contact killing.

For this reason, hydrophobic copper-sputtered surfaces were produced, meaning smooth PMMA surfaces, i.e., not roughened after oxygen plasma treatment, further sputtered with $10 \mathrm{~nm}$-thick copper film, followed by varying $\mathrm{C}_{4} \mathrm{~F}_{8}$ plasma deposition times of the fluorocarbon layer for $5,10,20$, and $30 \mathrm{~s}$. Contact angle measurements on the fluorocarbon surfaces resulted in an approximate value of $108^{\circ}$. Fifty microliters of Synechococcus sp. PCC 7942 of $4.6 \times 10^{9} \mathrm{cfu} / \mathrm{mL}$ concentration was added to the surfaces and the $\mathrm{Chl} \alpha$ fluorescence was measured using the proposed in situ susceptibility method until the end of their exponential growth with their evolution curves being shown in Figure 5a.

As can be seen in the graph, deposition times of 5 and 10 s present an obvious advantage over the larger times of 20 and $30 \mathrm{~s}$, by receiving negative values of $M_{i}$ index indicative of the decline in the bacterial population and, thus, the antibacterial activity. An enhanced antibacterial behavior of the $5 \mathrm{~s}$ deposited fluorocarbon layer surfaces is deployed compared to the $10 \mathrm{~s}$, with an earlier and more intense expression of the $M_{i}$ negative values, as reaffirmed by the greater slope of the corresponding graph. The results could be interpreted as hampering the copper ions diffusion to the surface with the increase of the hydrophobic coating thickness.

Given the need for a balance between an adequate, yet controlled, release rate of copper ions to achieve prolonged bactericidal activity, the same deposition times were examined for superhydrophobic surfaces, roughened in oxygen plasma, and enriched with the same copper quantity (10 nm thickness). The water static contact angle measurements of the $10 \mathrm{~nm}$ copper-sputtered micro-nanotextured surfaces for all the varying fluorocarbon deposition times $(5,10,20$, and $30 \mathrm{~s})$ resulted in $160^{\circ}\left( \pm 2^{\circ}\right)$, with respective contact angle hysteresis lower than $5^{\circ}$, in all cases. From the results shown in Figure $5 \mathrm{~b}$, the antibacterial activity of the $10 \mathrm{~s}$ deposited fluorocarbon layer outperforms the 5, 20, and $30 \mathrm{~s}$ deposited surfaces. The better bactericidal activity displayed for the $10 \mathrm{~s}$ fluorocarbon deposition indicates the effect of surface roughness, which demands a higher deposition time for creating a superhydrophobic, anti-adhesive surface. Following the same rationale, the $10 \mathrm{~s}$ deposition time of 
hydrophobic layer was opted for the greater quantity of $15 \mathrm{~nm}$ copper film finally engrafted in the "hybrid" antibacterial surfaces [34].

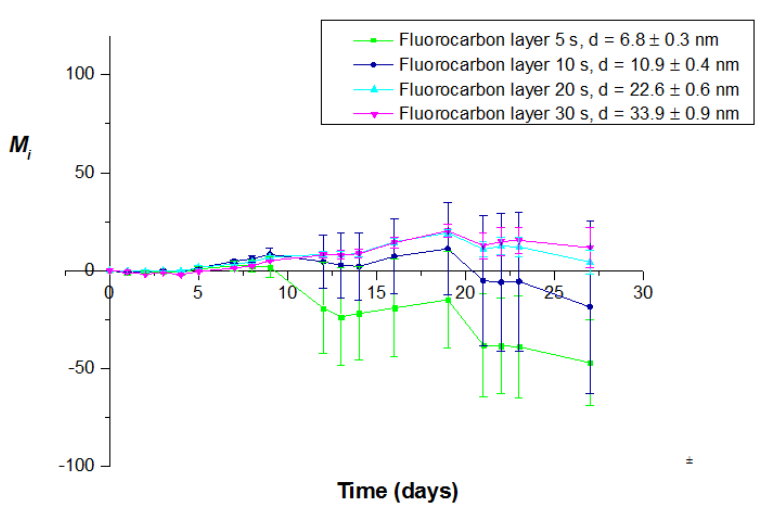

(a)

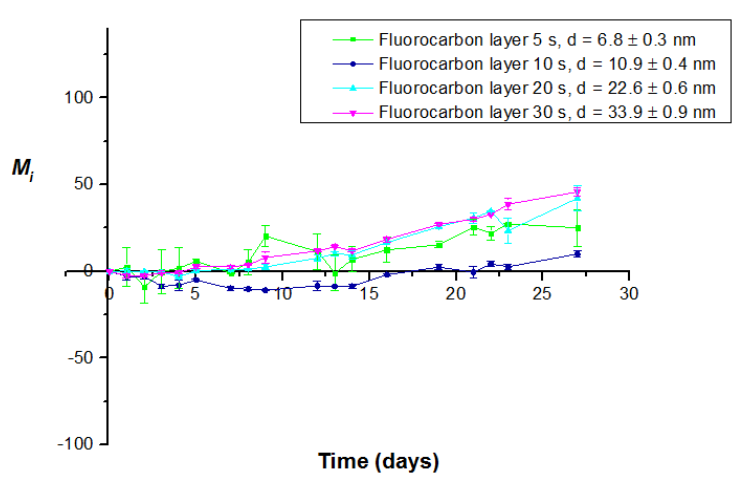

(b)

Figure 5. Antibacterial activity of copper-enriched (a) hydrophobic and (b) micro-nanotextured superhydrophobic PMMA surfaces coated with fluorocarbon layer from $\mathrm{C}_{4} \mathrm{~F}_{8}$ gas discharge for varying deposition times of 5, 10, 20, and $30 \mathrm{~s}$ alongside with the analogous coating thickness $\mathrm{d}$. For the hydrophobic surfaces, optimal antibacterial activity is observed for fluorocarbon layer deposition of 5 and $10 \mathrm{~s}$ (6.8 and $10.9 \mathrm{~nm}$ thickness, respectively), and is reduced for longer deposition times. For the superhydrophobic surfaces, $5 \mathrm{~s}$ deposition is not enough to cover the surface roughness, thus $10 \mathrm{~s}$ deposition gives the optimal behavior, combining superhydrophobicity with optimum copper diffusion for the bactericidal activity.

Finally, it should be noted that the same bacterial volume concentration $\left(4.6 \times 10^{9} \mathrm{cfu} / \mathrm{mL}\right)$, deposited on both the untreated and plasma-treated PMMA surfaces, corresponds to different bacterial surface density and in particular, approximately twenty times higher on the treated surfaces (see Section 3.1), given the significantly lower contact area of the bacterial solution with their micro-nanotextured surface $\left(1.7 \times 10^{8}\right.$ and $33.2 \times 10^{8} \mathrm{cfu} / \mathrm{cm}^{2}$ on the untreated and treated surfaces, respectively) (see supporting information of [34]). This deters us from any direct comparison between untreated and treated surfaces in terms of bactericidal performance. What is most important is to point out the remarkable antibacterial activity (up to 16 days) of the "hybrid" copper-sputtered and $10 \mathrm{~s}$ fluorocarbon-coated, micro-nanotextured (superhydrophobic) PMMA surfaces at extremely high bacterial concentrations $\left(4.6 \times 10^{9} \mathrm{cfu} / \mathrm{mL}\right)$, one of the highest ever reported in the literature.

\section{Conclusions}

We thereby presented the optimization procedure for creating "hybrid" metal-sputtered, superhydrophobic antibacterial surfaces, capable of a dual-function activity that encompasses both anti-adhesive and bactericidal properties. In terms of its bactericidal mode of action, among the two tested antibacterial agents, silver and copper, the latter was chosen due to its evident outperformance in terms of both killing potential and long-term durability at high bacterial concentrations. This conclusion tallies with copper's better efficiency in dry contact killing at ambient conditions. For the surface anti-adhesive activity, the optimization process involved two low surface energy hydrophobic coatings: a chlorosilane and a fluorocarbon coating. While both maintained their anti-adhesive properties when immersed in bacterial solution of sufficient concentration $\left(2.3 \times 10^{9} \mathrm{cfu} / \mathrm{mL}\right)$ for as long as 3 days, the fluorocarbon layer managed to better secure the superhydrophobicity and anti-adhesiveness of the surface when enriched with an adequate amount $(10 \mathrm{~nm})$ of copper biocide. Finally, the thickness of the fluorocarbon layer was optimized for a deposition time of $10 \mathrm{~s}$ (approximately 10-11 nm thickness), enough to secure both the superhydrophobic properties of the surface and the sustained release of the $\mathrm{Cu}^{2+}$ ions via diffusion through the layer for long-term bactericidal action. 
Author Contributions: Conceptualization, A.T. and E.G.; methodology, K.E., K.S., E.G. and A.T.; validation, K.E., D.K. and K.S.; formal analysis, D.K. and K.E.; investigation, K.E., D.K. and T.S.; resources, K.S., E.G. and T.S. (thin film growth); writing—original draft preparation, D.K.; writing—review and editing, A.T., K.E., K.S. and E.G.; visualization, D.K.; supervision, A.T., E.G. and K.S.; project administration, E.G. and A.T. All authors have read and agreed to the published version of the manuscript.

Funding: The authors kindly acknowledge partial support of this work by the project "Development of Materials and Devices for Industrial, Health, Environmental and Cultural Applications" (MIS 5002567), funded by the Operational Program "Competitiveness, Entrepreneurship and Innovation" (NSRF 2014-2020) and co-financed by Greece and the European Union.

Conflicts of Interest: The authors declare no conflict of interest.

\section{References}

1. Banerjee, I.; Pangule, R.C.; Kane, R.S. Antifouling Coatings: Recent Developments in the Design of Surfaces That Prevent Fouling by Proteins, Bacteria, and Marine Organisms. Adv. Mater. 2011, 23, 690-718. [CrossRef]

2. Hu, D.; Li, H.; Wang, B.; Ye, Z.; Lei, W.; Jia, F.; Jin, Q.; Ren, K.F.; Ji, J. Surface-Adaptive Gold Nanoparticles with Effective Adherence and Enhanced Photothermal Ablation of Methicillin-Resistant Staphylococcus Aureus Biofilm. ACS Nano 2017, 11, 9330-9339. [CrossRef] [PubMed]

3. Andersson, D.I.; Hughes, D. Antibiotic resistance and its cost: Is it possible to reverse resistance? In Nature Reviews Microbiology; Nature Publishing Group: New York, NY, USA, 2010; pp. 260-271.

4. Ladd, A.P.; Levy, M.S.; Quilty, J. Minimally Invasive Technique in Treatment of Complex, Subcutaneous Abscesses in Children. J. Pediatr. Surg. 2010, 45, 1562-1566. [CrossRef]

5. Mi, G.; Shi, D.; Wang, M.; Webster, T.J. Reducing bacterial infections and biofilm formation using nanoparticles and nanostructured antibacterial surfaces. In Advanced Healthcare Materials; John Wiley \& Sons: New York, NY, USA, 2018; pp. 1-23.

6. Tejido-Rastrilla, R.; Ferraris, S.; Goldmann, W.H.; Grünewald, A.; Detsch, R.; Baldi, G.; Spriano, S.; Boccaccini, A.R. Studies on Cell Compatibility, Antibacterial Behavior, and Zeta Potential of Ag-Containing Polydopamine-Coated Bioactive Glass-Ceramic. Materials 2019, 12, 500. [CrossRef] [PubMed]

7. Centers for Disease Control and Prevention. Available online: https://www.cdc.gov/drugresistance/index. html (accessed on 6 September 2019).

8. Tripathy, A.; Kumar, A.; Sreedharan, S.; Muralidharan, G.; Pramanik, A.; Nandi, D.; Sen, P. Fabrication of Low-Cost Flexible Superhydrophobic Antibacterial Surface with Dual-Scale Roughness. ACS Biomater. Sci. Eng. 2018, 4, 2213-2223. [CrossRef]

9. Wu, S.; Zhang, B.; Liu, Y.; Suo, X.; Li, H. Influence of Surface Topography on Bacterial Adhesion: A Review (Review). Biointerphases 2018, 13, 060801. [CrossRef] [PubMed]

10. Yuan, Y.; Hays, M.P.; Hardwidge, P.R.; Kim, J. Surface Characteristics Influencing Bacterial Adhesion to Polymeric Substrates. RSC Adv. 2017, 7, 14254-14261. [CrossRef]

11. Buxadera-Palomero, J.; Canal, C.; Torrent-Camarero, S.; Garrido, B.; Javier Gil, F.; Rodríguez, D. Antifouling Coatings for Dental Implants: Polyethylene Glycol-like Coatings on Titanium by Plasma Polymerization. Biointerphases 2015, 10, 029505. [CrossRef] [PubMed]

12. Gour, N.; Ngo, K.X.; Vebert-Nardin, C. Anti-Infectious Surfaces Achieved by Polymer Modification. Macromol. Mater. Eng. 2014, 299, 648-668. [CrossRef]

13. Liu, L.; Ercan, B.; Sun, L.; Ziemer, K.S.; Webster, T.J. Understanding the Role of Polymer Surface Nanoscale Topography on Inhibiting Bacteria Adhesion and Growth. ACS Biomater. Sci. Eng. 2016, 2, 122-130. [CrossRef]

14. Lüdecke, C.; Roth, M.; Yu, W.; Horn, U.; Bossert, J.; Jandt, K.D. Nanorough Titanium Surfaces Reduce Adhesion of Escherichia Coli and Staphylococcus Aureus via Nano Adhesion Points. Colloids Surf. B Biointerfaces 2016, 145, 617-625. [CrossRef] [PubMed]

15. Bruzaud, J.; Tarrade, J.; Celia, E.; Darmanin, T.; Taffin de Givenchy, E.; Guittard, F.; Herry, J.M.; Guilbaud, M.; Bellon-Fontaine, M.N. The Design of Superhydrophobic Stainless Steel Surfaces by Controlling Nanostructures: A Key Parameter to Reduce the Implantation of Pathogenic Bacteria. Mater. Sci. Eng. C 2017, 73, 40-47. [CrossRef] [PubMed] 
16. Hasan, J.; Webb, H.K.; Truong, V.K.; Pogodin, S.; Baulin, V.A.; Watson, G.S.; Watson, J.A.; Crawford, R.J.; Ivanova, E.P. Selective Bactericidal Activity of Nanopatterned Superhydrophobic Cicada Psaltoda Claripennis Wing Surfaces. Appl. Microbiol. Biotechnol. 2013, 97, 9257-9262. [CrossRef] [PubMed]

17. Bassegoda, A.; Ivanova, K.; Ramon, E.; Tzanov, T. Strategies to Prevent the Occurrence of Resistance against Antibiotics by Using Advanced Materials. Appl. Microbiol. Biotechnol. 2018, 102, 2075-2089. [CrossRef] [PubMed]

18. Karaman, D.Ş.; Manner, S.; Fallarero, A.; Rosenholm, J.M. Current approaches for exploration of nanoparticles as antibacterial agents. In Antibacterial Agents; Kumavath, R., Ed.; InTechOpen: London, UK, 2017; pp. 63-67.

19. Jankauskaite, V.; Lazauskas, A.; Gri Konis, E.; Lisauskaite, A.; Ukiene, K. UV-Curable Aliphatic Silicone Acrylate Organic-Inorganic Hybrid Coatings with Antibacterial Activity. Molecules 2017, 22, 964. [CrossRef] [PubMed]

20. Cai, R.; Tao, G.; He, H.; Song, K.; Zuo, H.; Jiang, W.; Wang, Y. One-Step Synthesis of Silver Nanoparticles on Polydopamine-Coated Sericin/Polyvinyl Alcohol Composite Films for Potential Antimicrobial Applications. Molecules 2017, 22, 721. [CrossRef] [PubMed]

21. Noyce, J.O.; Michels, H.; Keevil, C.W. Use of Copper Cast Alloys to Control Escherichia Coli O157 Cross-Contamination during Food Processing. Appl. Environ. Microbiol. 2006, 72, 4239-4244. [CrossRef]

22. Cady, N.C.; Behnke, J.L.; Strickland, A.D. Copper-Based Nanostructured Coatings on Natural Cellulose: Nanocomposites Exhibiting Rapid and Efficient Inhibition of a Multi-Drug Resistant Wound Pathogen, A. Baumannii, and Mammalian Cell Biocompatibility in Vitro. Adv. Funct. Mater. 2011, 21, 2506-2514. [CrossRef]

23. Al-Bakri, A.G.; Mahmoud, N.N. Photothermal-Induced Antibacterial Activity of Gold Nanorods Loaded into Polymeric Hydrogel against Pseudomonas Aeruginosa Biofilm. Molecules 2019, 24, 2661. [CrossRef]

24. Ren, G.; Hu, D.; Cheng, E.W.C.; Vargas-Reus, M.A.; Reip, P.; Allaker, R.P. Characterisation of Copper Oxide Nanoparticles for Antimicrobial Applications. Int. J. Antimicrob. Agents 2009, 33, 587-590. [CrossRef]

25. Cioffi, N.; Torsi, L.; Ditaranto, N.; Tantillo, G.; Ghibelli, L.; Sabbatini, L.; Bleve-Zacheo, T.; D'Alessio, M.; Zambonin, P.G.; Traversa, E. Copper Nanoparticle/Polymer Composites with Antifungal and Bacteriostatic Properties. Chem. Mater. 2005, 17, 5255-5262. [CrossRef]

26. Schwartz, V.B.; Thétiot, F.; Ritz, S.; Pütz, S.; Choritz, L.; Lappas, A.; Förch, R.; Landfester, K.; Jonas, U. Antibacterial Surface Coatings from Zinc Oxide Nanoparticles Embedded in Poly(N-Isopropylacrylamide) Hydrogel Surface Layers. Adv. Funct. Mater. 2012, 22, 2376-2386. [CrossRef]

27. Khani, A.; Talebian, N. In Vitro Bactericidal Effect of Ultrasonically Sol-Gel-Coated Novel $\mathrm{CuO} / \mathrm{TiO}_{2} / \mathrm{PEG} /$ Cotton Nanocomposite for Wound Care. J. Coat. Technol. Res. 2017, 14, 651-663. [CrossRef]

28. Verdier, T.; Coutand, M.; Bertron, A.; Roques, C. Antibacterial Activity of $\mathrm{TiO}_{2}$ Photocatalyst Alone or in Coatings on E. coli: The Influence of Methodological Aspects. Coatings 2014, 4, 670-686. [CrossRef]

29. Elena, P.; Miri, K. Formation of Contact Active Antimicrobial Surfaces by Covalent Grafting of Quaternary Ammonium Compounds. Colloids Surf. B Biointerfaces 2018, 169, 195-205. [CrossRef]

30. Pant, J.; Gao, J.; Goudie, M.J.; Hopkins, S.P.; Locklin, J.; Handa, H. A Multi-Defense Strategy: Enhancing Bactericidal Activity of a Medical Grade Polymer with a Nitric Oxide Donor and Surface-Immobilized Quaternary Ammonium Compound. Acta Biomater. 2017, 58, 421-431. [CrossRef]

31. Bazaka, K.; Jacob, M.V.; Chrzanowski, W.; Ostrikov, K. Anti-Bacterial Surfaces: Natural Agents, Mechanisms of Action, and Plasma Surface Modification. RSC Adv. 2015, 5, 48739-48759. [CrossRef]

32. Ivanova, E.P.; Hasan, J.; Webb, H.K.; Gervinskas, G.; Juodkazis, S.; Truong, V.K.; Wu, A.H.F.; Lamb, R.N.; Baulin, V.A.; Watson, G.S.; et al. Bactericidal Activity of Black Silicon. Nat. Commun. 2013, 4, 2838. [CrossRef]

33. Vassallo, E.; Pedroni, M.; Silvetti, T.; Morandi, S.; Toffolatti, S.; Angella, G.; Brasca, M. Bactericidal Performance of Nanostructured Surfaces by Fluorocarbon Plasma. Mater. Sci. Eng. C 2017, 80, 117-121. [CrossRef]

34. Ellinas, K.; Kefallinou, D.; Stamatakis, K.; Gogolides, E.; Tserepi, A. Is There a Threshold in the Antibacterial Action of Superhydrophobic Surfaces? ACS Appl. Mater. Interfaces 2017, 9, 39781-39789. [CrossRef]

35. Ren, T.; Yang, M.; Wang, K.; Zhang, Y.; He, J. CuO Nanoparticles-Containing Highly Transparent and Superhydrophobic Coatings with Extremely Low Bacterial Adhesion and Excellent Bactericidal Property. ACS Appl. Mater. Interfaces 2018, 10, 25717-25725. [CrossRef] [PubMed]

36. Qian, H.; Li, M.; Li, Z.; Lou, Y.; Huang, L.; Zhang, D.; Xu, D.; Du, C.; Lu, L.; Gao, J. Mussel-Inspired Superhydrophobic Surfaces with Enhanced Corrosion Resistance and Dual-Action Antibacterial Properties. Mater. Sci. Eng. C 2017, 80, 566-577. [CrossRef] [PubMed] 
37. Ozkan, E.; Crick, C.C.; Taylor, A.; Allan, E.; Parkin, I.P. Copper-Based Water Repellent and Antibacterial Coatings by Aerosol Assisted Chemical Vapour Deposition. Chem. Sci. 2016, 7, 5126-5131. [CrossRef] [PubMed]

38. Heinonen, S.; Huttunen-Saarivirta, E.; Nikkanen, J.P.; Raulio, M.; Priha, O.; Laakso, J.; Storgårds, E.; Levänen, E. Antibacterial Properties and Chemical Stability of Superhydrophobic Silver-Containing Surface Produced by Sol-Gel Route. Colloids Surfaces A Physicochem. Eng. Asp. 2014, 453, 149-161. [CrossRef]

39. Ellinas, K.; Tserepi, A.; Gogolides, E. Durable Superhydrophobic and Superamphiphobic Polymeric Surfaces and Their Applications: A Review. Adv. Colloid Interface Sci. 2017, 250, 132-157. [CrossRef] [PubMed]

40. Sarkiris, P.; Ellinas, K.; Gkiolas, D.; Mathioulakis, D.; Gogolides, E. Motion of Drops with Different Viscosities on Micro-Nanotextured Surfaces of Varying Topography and Wetting Properties. Adv. Funct. Mater. 2019, 29, 1902905. [CrossRef]

41. Kontziampasis, D.; Boulousis, G.; Smyrnakis, A.; Ellinas, K.; Tserepi, A.; Gogolides, E. Biomimetic, Antireflective, Superhydrophobic and Oleophobic PMMA and PMMA-Coated Glass Surfaces Fabricated by Plasma Processing. Microelectron. Eng. 2014, 121, 33-38. [CrossRef]

42. Gogolides, E.; Ellinas, K.; Tserepi, A. Hierarchical Micro and Nano Structured, Hydrophilic, Superhydrophobic and Superoleophobic Surfaces Incorporated in Microfluidics, Microarrays and Lab on Chip Microsystems. Microelectron. Eng. 2015, 132, 135-155. [CrossRef]

43. Ellinas, K.; Tserepi, A.; Gogolides, E. From Superamphiphobic to Amphiphilic Polymeric Surfaces with Ordered Hierarchical Roughness Fabricated with Colloidal Lithography and Plasma Nanotexturing. Langmuir 2011, 27, 3960-3969. [CrossRef]

44. Vourdas, N.; Tserepi, A.; Gogolides, E. Nanotextured Super-Hydrophobic Transparent Poly(Methyl Methacrylate) Surfaces Using High-Density Plasma Processing. Nanotechnology 2007, 18, 125304. [CrossRef]

45. Tarrade, J.; Darmanin, T.; Taffin De Givenchy, E.; Guittard, F.; Debarnot, D.; Poncin-Epaillard, F. Texturation and Superhydrophobicity of Polyethylene Terephthalate Thanks to Plasma Technology. Appl. Surf. Sci. 2014, 292, 782-789. [CrossRef]

46. Rippka, R.; Deruelles, J.; Waterbury, J.B.; Herdman, M.; Stanier, R.Y. Generic Assignments, Strain Histories and Properties of Pure Cultures of Cyanobacteria. J. Gen. Microbiol. 1979, 111, 1-61. [CrossRef]

47. Moran, R. Formulae for Determination of Chlorophyllous Pigments Extracted with N,N-dimethylformamide. Plant Physiol. 1982, 69, 1376-1381. [CrossRef] [PubMed]

48. Heliopoulos, N.S.; Galeou, A.; Papageorgiou, S.K.; Favvas, E.P.; Katsaros, F.K.; Stamatakis, K. An in Situ Antimicrobial Susceptibility Testing Method Based on in Vivo Measurements of Chlorophyll $\alpha$ Fluorescence. J. Microbiol. Methods 2015, 112, 49-54. [CrossRef] [PubMed]

49. Heliopoulos, N.S.; Galeou, A.; Papageorgiou, S.K.; Favvas, E.P.; Katsaros, F.K.; Stamatakis, K. Modified in Situ Antimicrobial Susceptibility Testing Method Based on Cyanobacteria Chlorophyll a Fluorescence. J. Microbiol. Methods 2016, 121, 1-4. [CrossRef]

50. Tsougeni, K.; Vourdas, N.; Tserepi, A.; Gogolides, E.; Cardinaud, C. Mechanisms of Oxygen Plasma Nanotexturing of Organic Polymer Surfaces: From Stable Super Hydrophilic to Super Hydrophobic Surfaces. Langmuir 2009, 25, 11748-11759. [CrossRef]

51. Luo, J.; Hein, C.; Mücklich, F.; Solioz, M. Killing of Bacteria by Copper, Cadmium, and Silver Surfaces Reveals Relevant Physicochemical Parameters. Biointerphases 2017, 12, 020301. [CrossRef]

52. Le Ouay, B.; Stellacci, F. Antibacterial Activity of Silver Nanoparticles: A Surface Science Insight. Nano Today 2015, 10, 339-354. [CrossRef]

53. Nakamura, S.; Sato, M.; Sato, Y.; Ando, N.; Takayama, T.; Fujita, M.; Ishihara, M. Synthesis and Application of Silver Nanoparticles (Ag NPs) for the Prevention of Infection in Healthcare Workers. Int. J. Mol. Sci. 2019, 20, 3620. [CrossRef]

54. Liu, J.; Hurt, R.H. Ion Release Kinetics and Particle Persistence in Aqueous Nano-Silver Colloids. Environ. Sci. Technol. 2010, 44, 2169-2175. [CrossRef]

55. Zeiger, M.; Solioz, M.; Edongué, H.; Arzt, E.; Schneider, A.S. Surface Structure Influences Contact Killing of Bacteria by Copper. Microbiologyopen 2014, 3, 327-332. [CrossRef] [PubMed]

56. Grass, G.; Rensing, C.; Solioz, M. Metallic Copper as an Antimicrobial Surface. Appl. Environ. Microbiol. 2011, 77, 541-1547. [CrossRef] [PubMed]

57. Santo, C.E.; Taudte, N.; Nies, D.H.; Grass, G. Contribution of Copper Ion Resistance to Survival of Escherichia Coli on Metallic Copper Surfaces. Appl. Environ. Microbiol. 2008, 74, 977-986. [CrossRef] [PubMed] 
58. Santo, C.E.; Lam, E.W.; Elowsky, C.G.; Quaranta, D.; Domaille, D.W.; Chang, C.J.; Grass, G. Bacterial Killing by Dry Metallic Copper Surfaces. Appl. Environ. Microbiol. 2011, 77, 794-802. [CrossRef]

59. Hans, M.; Mathews, S.; Mücklich, F.; Solioz, M. Physicochemical Properties of Copper Important for Its Antibacterial Activity and Development of a Unified Model. Biointerphases 2016, 11, 018902. [CrossRef]

60. He, C.; Chen, Q.; Yarmolenko, M.A.; Rogachev, A.A.; Piliptsou, D.G.; Jiang, X.; Rogachev, A.V. Structure and Antibacterial Activity of PLA-Based Biodegradable Nanocomposite Coatings by Electron Beam Deposition From Active Gas Phase. Prog. Org. Coat. 2018, 123, 282-291. [CrossRef]

61. Sun, D.; Xu, D.; Yang, C.; Chen, J.; Shahzad, M.B.; Sun, Z.; Zhao, J.; Gu, T.; Yang, K.; Wang, G. Inhibition of Staphylococcus Aureus Biofilm by a Copper-Bearing 317L-Cu Stainless Steel and Its Corrosion Resistance. Mater. Sci. Eng. C 2016, 69, 744-750. [CrossRef]

62. Elguindi, J.; Wagner, J.; Rensing, C. Genes Involved in Copper Resistance Influence Survival of Pseudomonas Aeruginosa on Copper Surfaces. J. Appl. Microbiol. 2009, 106, 1448-1455. [CrossRef]

63. Ellinas, K.; Pujari, P.S.; Dragatogiannis, D.A.; Charitidis, C.A.; Tserepi, A.; Zuilhof, H.; Gogolides, E. Plasma Micro-Nanotextured, Scratch, Water and Hexadecane Resistant, Superhydrophobic, and Superamphiphobic Polymeric Surfaces with Perfluorinated Monolayers. ACS Appl. Mater. Interfaces 2014, 6, 6510-6524. [CrossRef]

64. Ellinas, K.; Tsougeni, K.; Petrou, P.S.; Boulousis, G.; Tsoukleris, D.; Pavlatou, E.; Tserepi, A.; Kakabakos, S.E.; Gogolides, E. Three-Dimensional Plasma Micro-Nanotextured Cyclo-Olefin-Polymer Surfaces for Biomolecule Immobilization and Environmentally Stable Superhydrophobic and Superoleophobic Behavior. Chem. Eng. J. 2016, 300, 394-403. [CrossRef]

(C) 2019 by the authors. Licensee MDPI, Basel, Switzerland. This article is an open access article distributed under the terms and conditions of the Creative Commons Attribution (CC BY) license (http://creativecommons.org/licenses/by/4.0/). 